\title{
Determining Oxidative Damage by Lipid Peroxidation Assay in Rat Serum
}

Qian Tang, Yu-Wen Su and Cory J. Xian*

School of Pharmacy and Medical Sciences, University of South Australia Cancer Research Institute, University of South Australia, Adelaide, SA 5001, Australia

*For correspondence: Cory.Xian@unisa.edu.au

[Abstract] It has been well-established that malondialdehyde (MDA), which is generated during the process of lipid peroxidation, is a commonly known biomarker for oxidative stress. Therefore, the serum levels of MDA are detected by using the lipid peroxidation assay with commercially available kit to determine the induction of oxidative stress in rat models.

Keywords: Oxidative stress, Malondialdehyde, Lipid peroxidation, Thiobarbituric acid, MDA-TBA adduct, Serum

[Background] As lipid peroxidation is the degradation of lipids that occurs as a result of oxidative damage and contributes to the pathology of many diseases, some end-products of the chain reaction of lipid peroxidation such as malondialdehyde (MDA), 4-Hydroxynonenal (4-HNE) and 8-iso-Prostaglandin F2alpha (8-isoprostane) in serum samples have been detected and quantified for the identification of oxidative damage (Marrocco et al., 2017). In the current lipid peroxidation assay protocol, the serum levels of MDA could be specifically and reliably quantified based on the condensation reaction between MDA and thiobarbituric acid (TBA) by modifying a commercially available kit (MAK085D; Sigma, St Louis, MO) without n-butanol precipitation step (Tang et al., 2019).

\section{Materials and Reagents}

1. Pipette tips

2. 96-well flat bottom microplate (Sigma-Aldrich, catalog number: CLS3610)

3. Separate tube (Corning, catalog number: CLS430791)

4. Double-distilled water $\left(\mathrm{ddH}_{2} \mathrm{O}\right)$

5. Ice

6. $60 \mu \mathrm{l}$ freshly collected rat serum

7. TBA (Sigma-Aldrich, catalog number: MAK085D)

8. Glacial acetic acid (Sigma-Aldrich, catalog number: A6283)

9. 4.17 M MDA standard (Sigma-Aldrich, catalog number: MAK085E)

10. $42 \mathrm{mM}$ Sulfuric acid solution (Sigma-Aldrich, catalog number: 84736)

11. Phosphotungstic acid solution (PTA) (Sigma-Aldrich, catalog number: MAK085B)

12. Butylated hydroxytoluene (BHT) (Sigma-Aldrich, catalog number: MAK085C)

13. MDA standard (see Recipes) 


\section{Equipment}

1. Pipettes (Bio-rad, P10, P200 and P1000)

2. Vortexer (Ratek, catalog number: VM1)

3. Centrifuge (Thermoline, model: K1015 Pro)

4. Incubator (Robbins Scientific, catalog number: 2000)

5. Microplate reader (Perkin Elmer, catalog number: 1420 Victor3)

\section{Software}

1. Microsoft Excel 2010

\section{Procedure}

The flow chart in Figure 1 shows all the steps described in this protocol.

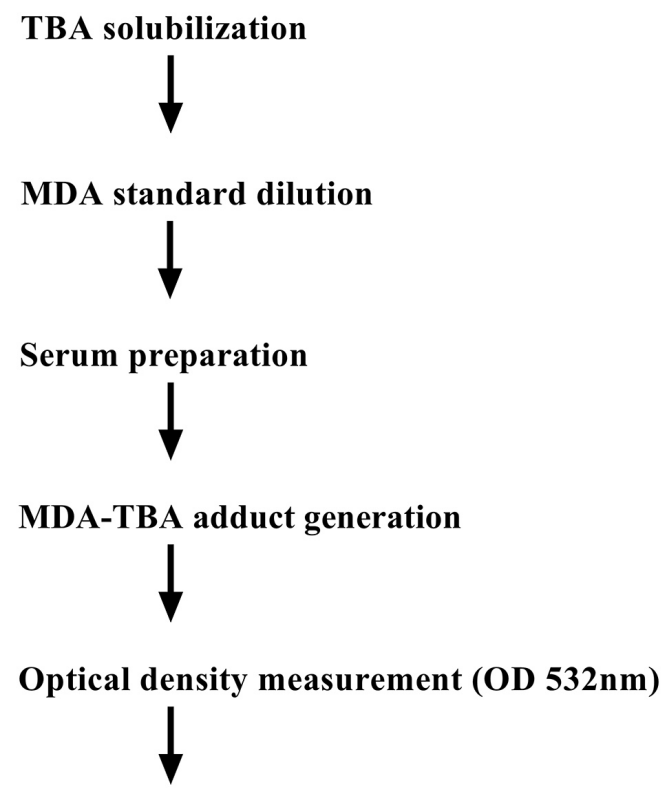

\section{MDA standard curve generation}

Figure 1. Schematic diagram of the assay procedure

1. Reconstitute a bottle of TBA with $7.5 \mathrm{ml}$ glacial acetic acid followed by adjusting with $\mathrm{ddH}_{2} \mathrm{O}$ to make $25 \mathrm{ml}$ TBA solution.

2. Dilute $10 \mu \mathrm{l}$ of $4.17 \mathrm{M} \mathrm{MDA}$ standard in $407 \mu \mathrm{l}$ of $\mathrm{dd}_{2} \mathrm{O}$ to make $0.1 \mathrm{M}$ MDA standard.

3. Dilute $10 \mu \mathrm{l}$ of $0.1 \mathrm{M}$ MDA standard in $490 \mu \mathrm{l}$ of $\mathrm{ddH}_{2} \mathrm{O}$ to make $2 \mathrm{mM}$ MDA standard.

4. Use $2 \mathrm{mM}$ MDA standard to generate MDA standard curve dilutions (Recipe 1).

5. Mix $20 \mu \mathrm{l}$ of serum with $500 \mu \mathrm{l}$ of $42 \mathrm{mM}$ sulfuric acid. 
6. Add $125 \mu \mathrm{l}$ of PTA followed by vortexing.

7. Centrifuge at $13,000 \times g$ at room temperature for $5 \mathrm{~min}$.

8. Add $200 \mu \mathrm{l}$ of $\mathrm{BHT}$ to $10 \mathrm{ml}$ of $\mathrm{ddH}_{2} \mathrm{O}$ in a separate tube followed by vortexing.

9. Collect and resuspend serum pellet with $102 \mu \mathrm{l}$ of $\mathrm{BHT} / \mathrm{ddH}_{2} \mathrm{O}$ on ice.

10. Adjust the final volume to $200 \mu \mathrm{l}$ with $\mathrm{ddH}_{2} \mathrm{O}$ followed by vortexing.

11. Incubate at $37^{\circ} \mathrm{C}$ for $2 \mathrm{~h}$.

12. Mix $600 \mu \mathrm{l}$ of TBA solution with $200 \mu \mathrm{l}$ MDA standard/serum sample to generate $800 \mu \mathrm{l}$ of MDA-TBA adduct.

13. Incubate at $95^{\circ} \mathrm{C}$ for $1 \mathrm{~h}$ and then place on ice bath for $15 \mathrm{~min}$.

14. Pipette $200 \mu \mathrm{l}$ of MDA-TBA adduct into a 96 -well microplate in duplicate.

15. Measure the absorbance at a wavelength of $532 \mathrm{~nm}$ on the microplate reader.

16. Establish the standard curve using the serial dilutions of MDA standard.

17. Calculate MDA concentrations in serum samples.

\section{Data analysis}

1. Average the duplicate values for each reading.

2. Set the mean value of the blank (Standard \#1) as the background.

3. Correct for the background by subtracting the blank value from all readings.

4. Use the corrected values of MDA standards to plot a standard curve by using Microsoft Excel 2010 (Figure 2).

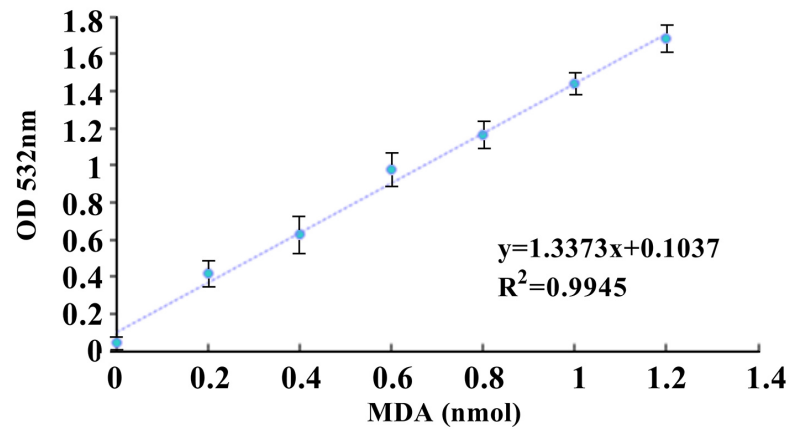

Figure 2. MDA standard curve. The standard curve was generated by using linear regression in Microsoft Excel 2010.

5. Obtain MDA amount in the sample wells based on the standard curve by using linear regression.

6. Concentration of MDA in the test serum samples is calculated as:

MDA concertation $=(A / 0.02 \mathrm{ml}) \times 4 \times D$

where, 
$A=$ Amount of MDA in sample calculated from the standard curve $(\mathrm{nmol})$.

$0.02 \mathrm{ml}=$ Original serum volume used $(200 \mu \mathrm{l})$.

$4=$ Correction for using $200 \mu$ of reaction mix from $800 \mu$ of MDA-TBA adduct.

$\mathrm{D}=$ Sample dilution factor (if sample is diluted to fit within the standard curve range).

\section{Notes}

1. Equilibrate all materials and prepared reagents to room temperature just prior to use and gently agitate.

2. Under the current experimental settings, the whole blood sample was centrifuged at $2,000 \times g$ at $4{ }^{\circ} \mathrm{C}$ for $10 \mathrm{~min}$ to collect serum. The serum was then immediately apportioned into $0.5 \mathrm{ml}$ aliquots and stored at $-20^{\circ} \mathrm{C}$.

3. A new standard curve must be set up each time the assay is run.

4. N-butanol precipitation step could be performed to enhance assay sensitivity where MDA-TBA adduct concentration is low in plasma samples.

\section{$\underline{\text { Recipes }}$}

1. MDA standard

\begin{tabular}{|c|c|c|c|c|}
\hline $\begin{array}{l}\text { Standard } \\
\#\end{array}$ & $\begin{array}{l}2 \text { mM MDA } \\
\text { standard volume }(\mu \mathrm{l})\end{array}$ & $\begin{array}{l}\text { dd } \mathrm{H}_{2} \mathrm{O} \text { volume } \\
(\mu \mathrm{l})\end{array}$ & $\begin{array}{l}\text { Final MDA standard } \\
\text { concertation }(\mu \mathrm{M})\end{array}$ & $\begin{array}{l}\text { Final MDA standard } \\
\text { amount (nmol/well) }\end{array}$ \\
\hline 1 & 0 & 600 & 0 & 0 \\
\hline 2 & 6 & 594 & 20 & 0.4 \\
\hline 3 & 12 & 588 & 40 & 0.8 \\
\hline 4 & 18 & 582 & 60 & 1.2 \\
\hline 5 & 24 & 576 & 80 & 1.6 \\
\hline 6 & 30 & 570 & 100 & 2.0 \\
\hline
\end{tabular}

\section{Acknowledgements}

CJX is supported by National Health and Medical Research Council of Australia (No. 1127396) and Natural Science Foundation of China (No. 81671928).

\section{Competing interests}

The authors declared that they have no conflict of interests to this work.

\section{$\underline{\text { References }}$}

1. Marrocco, I., Altieri, F. and Peluso, I. (2017). Measurement and clinical significance of biomarkers of oxidative stress in humans. Oxid Med Cell Longev 2017: 6501046. 
2. Tang, Q., Su, Y. W., Fan, C. M., Chung, R., Hassanshahi, M., Peymanfar, Y. and Xian, C. J. (2019). Release of CXCL12 from apoptotic skeletal cells contributes to bone growth defects following dexamethasone therapy in rats. J Bone Miner Res 34(2): 310-326. 